\title{
Effect of Heat treatment on Microstructure and Mechanical
}

\section{Properties of Ti-6Al-2Zr-1Mo-1V Bar}

\author{
Xu Enen ${ }^{a},{ }^{*}$, Tian Yanwen ${ }^{\mathrm{a}}$, Hao Fang ${ }^{\mathrm{a}}$, Cu Linin ${ }^{\mathrm{a}}$, Du Yuxuan ${ }^{\mathrm{a}}$, Lei Jinwen ${ }^{\mathrm{a}}$, Ju Biao ${ }^{\mathrm{a}}$ \\ ${ }^{\mathrm{a}}$ Western Superconducting Technologies Co.,Ltd., Xi'an, China \\ 761767918@qq.com
}

\begin{abstract}
$\underline{\text { Abstract }}$
In this paper, the microstructure evolution and mechanical properties fluctuation of Ti-6 Al-2Zr-1Mo-1V forging state bar after the first stage heat treatment at $950^{\circ} \mathrm{C} \sim 955^{\circ} \mathrm{C}$ and the second stage heat treatment at $760^{\circ} \mathrm{C} \sim 840^{\circ} \mathrm{C}$ were studied. In the first stage of heat treatment, the content of primary $\alpha$ and the tensile strength decreases with the increase of temperature, and the high temperature duration time is obviously prolonged. During the second stage of heat treatment, the metastable $\beta$ phase precipitates third $\alpha$ phase, and with the increase of temperature, the tensile strength increases and the high temperature duration time prolongs.
\end{abstract}

\section{Introduction}

Ti-6Al-2Zr-1Mo-1V is a kind of near- $\alpha$ titanium alloy with high aluminum equivalent, which has good thermal stability, corrosion resistance and weldability. It is widely used in aircraft structure and engine field. The microstructure of titanium alloy has an important effect on the properties ${ }^{[1-2]}$. In this paper, the microstructure and mechanical properties of Ti-6Al-2Zr-1Mo-1V forging state bar after the first stage heat treatment at $950^{\circ} \mathrm{C} \sim 955^{\circ} \mathrm{C}$ and the second stage heat treatment at $760^{\circ} \mathrm{C} \sim 840^{\circ} \mathrm{C}$ were studied.

\section{Material and Experiments}

The experimental material is Ti-6Al-2Zr-1Mo-1V forging state bar adding $0.035 \%$ Si element produced by Western Superconducting Technologies Co.,Ltd., The diameter of the bar is $350 \mathrm{~mm}$, and the phase transition point is $993^{\circ} \mathrm{C}$.

The first stage heat treatment temperature is $950^{\circ} \mathrm{C} / 2.5 \mathrm{~h} \mathrm{AC}$ or $955^{\circ} \mathrm{C} / 2.5 \mathrm{~h} \mathrm{AC}$, The second stage heat treatment is $760^{\circ} \mathrm{C} / 2.5 \mathrm{~h} \mathrm{AC}, 800^{\circ} \mathrm{C} / 2.5 \mathrm{~h}$ $\mathrm{AC}, 820^{\circ} \mathrm{C} / 2.5 \mathrm{~h} \mathrm{AC}$ or $840^{\circ} \mathrm{C} / 2.5 \mathrm{~h} \mathrm{AC}$.The sample numbers and the corresponding heat treatment status are shown in Table 1.

Table1 Sample number corresponding to different Heat treatment status

Sample Heat treatment condition
A $\quad$ Forging state sample, heat treatment stage at $840^{\circ} \mathrm{C}$
the first heat treatment stage at $950^{\circ} \mathrm{C}$, the second heat treatment stage at $840^{\circ} \mathrm{C}$
the first heat treatment stage at $955^{\circ} \mathrm{C}$, the second heat treatment stage at $840^{\circ} \mathrm{C}$
D
the first heat treatment stage at $955^{\circ} \mathrm{C}$, the second heat treatment stage at $760^{\circ} \mathrm{C}$

(C) The Authors, published by EDP Sciences. This is an open access article distributed under the terms of the Creative Commons Attribution License 4.0 (http://creativecommons.org/licenses/by/4.0/). 
The test temperature of high temperature tensile is $500^{\circ} \mathrm{C}$, the temperature of high temperature duration test is $500^{\circ} \mathrm{C}$, the stress is $470 \mathrm{MPa}$.

\section{Results and Discussion}

3.1 Effect of the first stage heat treatment on microstructure and properties

The optical micrographs of A, B and C samples were shown in Fig.1, and the scanning electron microscopy (SEM) images showed in Fig.2. The content of primary $\alpha$ phase (area fraction) of A, B, C is $60 \%, 52.4 \%, 44.6 \%$ respectively. After the first stage heating treatment, the primary $\alpha$ phase content decreased $7.6 \%$ and $15.4 \%$ after the forging state bar heated treatment at $950{ }^{\circ} \mathrm{C}$ and $955^{\circ} \mathrm{C}$, respectively. The thickness of the second $\alpha$ phase becomes thinner and the length increases.
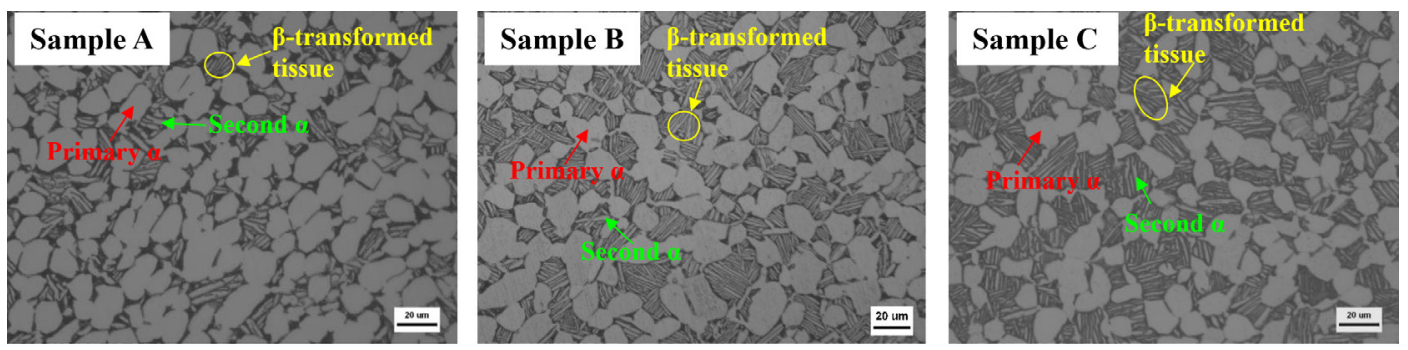

Fig.1 Optical micrographs of $\mathrm{A}, \mathrm{B}$ and $\mathrm{C}$
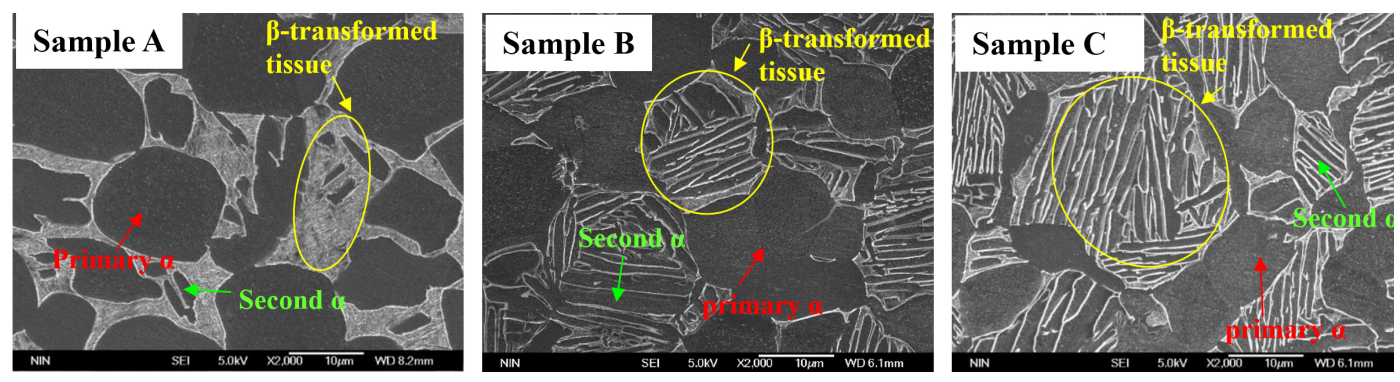

Fig.2 SEM images of $A, B$ and $C$

Table 2 The mechanical properties of $\mathrm{A}, \mathrm{B}$ and $\mathrm{C}$

\begin{tabular}{cccccc}
\hline Sample & $\mathrm{Rm} / \mathrm{MPa}$ & $\mathrm{Rp}_{0.2} / \mathrm{MPa}$ & $\mathrm{A} / \%$ & $\mathrm{Z} / \%$ & $\begin{array}{c}\text { High-temperature } \\
\text { duration time/h }\end{array}$ \\
\hline $\mathrm{A}$ & 1005 & 922.5 & 18.5 & 41 & 48.6
\end{tabular}


984.8

971
902.8

880
15.8

15.8
44.3

42.5
76.6

98

The mechanical properties of samples A, B and C are shown in Table 2. After the first stage of heat treatment and the second stage at $840^{\circ} \mathrm{C}$, the strength of the bar decreased and the high temperature duration time is significantly prolonged. The tensile strength and yield strength of sample $\mathrm{B}$ were about 20MPa lower than the sample A, but the change of elongation or surface shrinkage is not obvious, and the duration time is increased by 28 hours. The tensile strength of $\mathrm{C}$ sample is about $14 \mathrm{MPa}$ lower than that sample $\mathrm{B}$, and the duration is increased by 21.4 hours.

After heat treatment at $950^{\circ} \mathrm{C}$ or $955^{\circ} \mathrm{C}$, the content of $\beta$-transformed tissue increases, which leads to the increasing of dislocation slipping distance and the decreasing of the tensile strength. The high temperature duration time increases with the decrease of the content of primary $\alpha$ phase, which is due to the better durability of $\beta$ transformation structure than that of primary $\alpha$ phase ${ }^{[3-7]}$.

\subsection{Effect of the second stage heat treatment on microstructure and properties}

After the first stage of heat treatment at $955^{\circ} \mathrm{C}, \mathrm{D}, \mathrm{E}, \mathrm{F}$ and $\mathrm{C}$ were treated at $760^{\circ} \mathrm{C}, 800^{\circ} \mathrm{C}, 820^{\circ} \mathrm{C}$ and $840^{\circ} \mathrm{C}$ respectively. Their $2000 \times \mathrm{SEM}$ images are shown in Fig.3, the 10000× SEM images are shown in Fig.4, and the mechanical properties are shown in Table 3. The variations of tensile strength, yield and duration time for different temperature are shown in Fig.5, Fig.6.
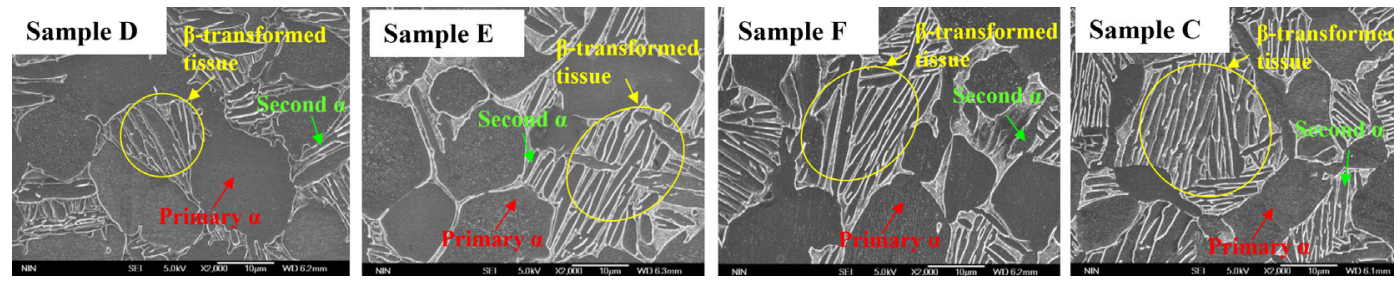

Fig.3 SEM images of D, E, F and C (2000 $\times)$
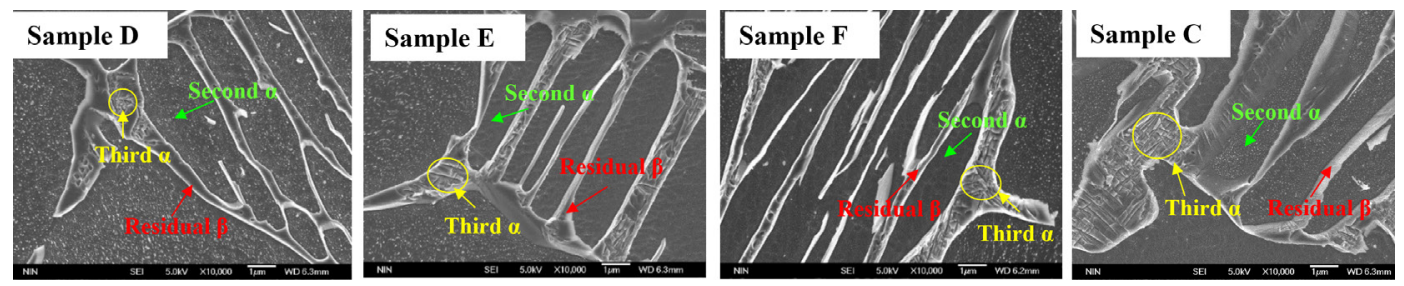

Fig.4 SEM images of D, E , F and C $(10000 \times)$

The third $\alpha$ phase precipitates in the residual $\beta$ phase, after the samples heated in the second stage of heat treatment. From Fig.4, it can be seen that with the increasing of temperature in the second stage of heat treatment, the content of the third $\alpha$ phase increases. As can be seen from Table 3 and Fig.5, Fig.6, the tensile strength and yield strength increases gradually with the increase of heating temperature, and the duration time is significantly prolonged. After heat treatment from $760^{\circ} \mathrm{C}$ to $840^{\circ} \mathrm{C}$, the tensile strength and yield strength at room temperature increase $43.5 \mathrm{MPa}, 19.3 \mathrm{MPa}$ respectively; the tensile strength and yield strength at $500^{\circ} \mathrm{C}$ temperature increase $36.3 \mathrm{MPa}, 11.8 \mathrm{MPa}$ respectively; and the high temperature duration time increases $40 \mathrm{~h}$.

Table 3 The mechanical properties of D, E, F and C 


\begin{tabular}{|c|c|c|c|c|c|c|c|}
\hline Sample & $\mathrm{Rm} / \mathrm{MPa}$ & $\mathrm{Rp} 0.2 / \mathrm{MPa}$ & $\mathrm{A} / \%$ & $\mathrm{Z} / \%$ & $500^{\circ} \mathrm{CRm}$ & $500^{\circ} \mathrm{CRp} 0.2$ & $\begin{array}{c}\text { High-temperature } \\
\text { duration time/h }\end{array}$ \\
\hline & & & & & $/ \mathrm{MPa}$ & $/ \mathrm{MPa}$ & \\
\hline D & 927.5 & 861 & 17 & 44 & 637 & 497.5 & 56 \\
\hline E & 960.5 & 881.5 & 17 & 42 & 651.5 & 493.5 & 66 \\
\hline F & 962 & 871.5 & 16.5 & 44 & 662.5 & 501.5 & 79 \\
\hline $\mathrm{C}$ & 971 & 880.3 & 15.8 & 42.5 & 673.3 & 509.3 & 96 \\
\hline
\end{tabular}

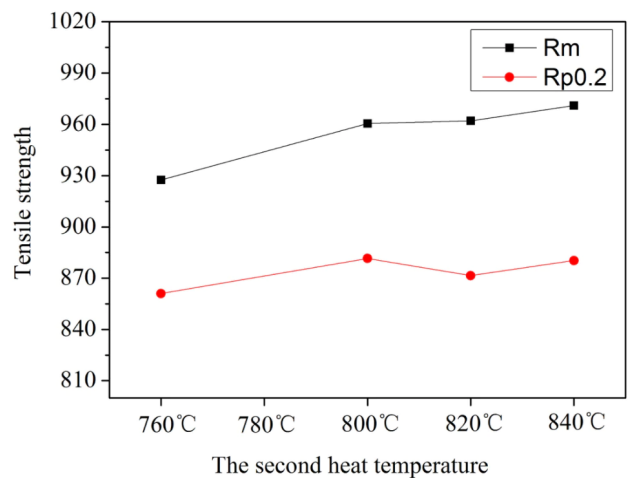

Fig.5 Tensile properties vary with temperature

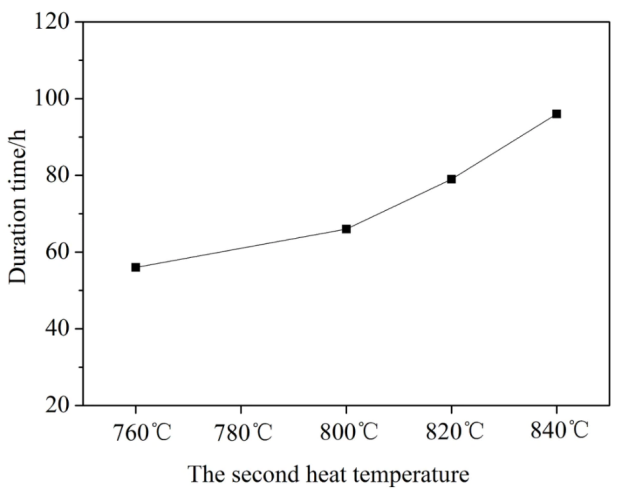


Fig.6 Duration time vary with temperature

\subsection{Analysis of rupture fracture}

The sample $\mathrm{C}$ first stage heat treatment temperature is $955^{\circ} \mathrm{C} / 2.5 \mathrm{~h} \mathrm{AC}$, and the second stage heat treatment is $840{ }^{\circ} \mathrm{C} / 2.5 \mathrm{~h} \mathrm{AC}$. The tensile specimen of sample $\mathrm{C}$ is fractured by tensile stress at room temperature, and its elongation is $18 \%$. The longitudinal section of the rupture fracture is shown in Fig.7. It can be seen that the primary $\alpha$-phase and the $\beta$-transformed tissue is elongated along the tensile stress direction. There are some holes near the fracture surface, all of which are at the interface of primary $\alpha$ phase and $\beta$-transformed tissue, indicating that the holes tend to initiate and expand at the interface of primary $\alpha$ phase and the $\beta$-transformed tissue, and cracks are formed when the holes grow and polymerize.
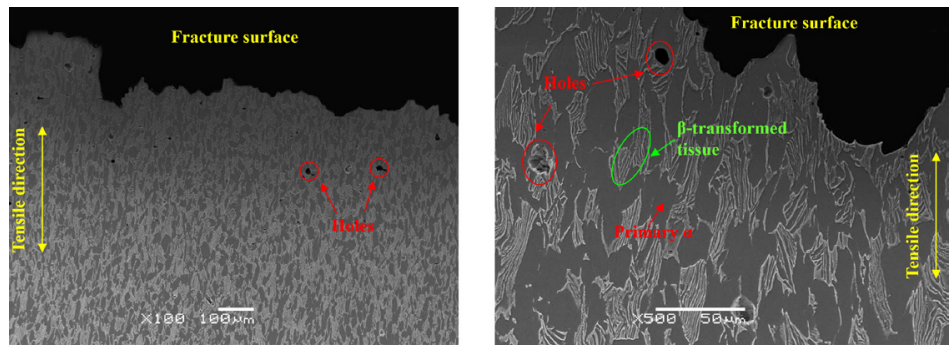

Fig.7 The longitudinal section of the rupture fracture

\section{Conclusion}

1. After the first stage of heat treatment at $950^{\circ} \mathrm{C} \sim 955^{\circ} \mathrm{C}$, the content of primary $\alpha$ phase decreases, and the thickness of the second $\alpha$ tends to thin.

2. After the first stage of heat treatment, the content of the $\beta$-transformed tissue increases, which results in the decreasing of the tensile strength and the prolongation of the duration time.

3. With the increasing of heating temperature in the second stage, the content of the third $\alpha$ phase precipitated from the residual $\beta$ phase increases, the tensile strength increases, and the duration time prolongs gradually.

4. The cracks tend to initiate and propagate at the interface of primary $\alpha$ phase and the $\beta$-transformed tissue during tensile test.

\section{$\underline{\text { 5. Acknowledgements }}$}

I would like to extend my gratitude to my supervisor Du Yuxuan and Lei Jinwen, for their instructive advice and useful suggestions on my thesis. I am indebted to my parents and my wife for their continuous encourage and support.

\section{$\underline{\text { 6. References }}$}

[1] Filip R, Kubiak K, Ziajia W. ,Journal of meterials Processing Processing Technology. 133 (2003) 84-89.

[2] Zhu Jingchuan, Wang Yang, You fanghui, Liu Yong, Lai Zhonghong, Transactions of Materials and Heat Treatment. 28 (2007) 106-109.

[3] Mo Wei, Ma Jimin. Titanium Ingot and Forging[M]. Beijing: Metallurgical Industry press, 2012: $161 \sim 162$.

[4] Mcandrew J B, Kessler H D.J, Metals. 10 (1956) 1348.

[5] Fentiman W P. The Science Technology and Application of Titanium[M]. London: Pergoman Press, $1970: 87$. 
[6] Lei Jiafeng, Li Dong, Wang Guangzong, Acta Metallurgica Sinica. 35 (1999) 184-186.

[7] R. T. Chen, W. H. Miller and E. A. Starke, 84'Titanium: Science and Technology. 1984: 2363-2370. 